\title{
THE IRON UPTAKE MECHANISMS OF ENTEROINVASIVE ESCHERICHIA COLI
}

\author{
Agda Andrade', Monique Dall’Agnol', Salete Newton ${ }^{2}$, Marina B. Martinez ${ }^{\text {" }}$ \\ ${ }^{1}$ Departamento de Análises Clínicas e Toxicológicas da Faculdade de Ciências Farmacêuticas, Universidade de São Paulo- \\ USP, São Paulo-SP, Brasil. ${ }^{2}$ Department of Chemistry and Biochemistry, University of Oklahoma, OK, USA
}

Submitted: December 10, 1999; Returned to authors for corrections: April 11, 2000; Approved: August 30, 2000

\begin{abstract}
Enteroinvasive Escherichia coli strains (EIEC) of different serotypes isolated from patients with acute diarrhea were examined for the ability to produce siderophores and iron-regulated outer membrane proteins (IROMP). For iron starvation cultures were grown at $37^{\circ} \mathrm{C}$ in LB supplied with $200 \mu \mathrm{M}$ of $\alpha$ - $\alpha$ 'dypirydil. All strains produced enterobactin and twelve (40\%) produced aerobactin. The strains showed IROMP varying from 67-82 $\mathrm{kDa}$. Proteins were either induced or stimulated by the iron starvation. Differences were observed in the electrophoretic profile among the serotypes, originating 5 electrophoretic profiles. All serotypes expressed proteins of $82 \mathrm{kDa}(\mathrm{FepA})$ and $76 \mathrm{kDa}$ (IutA) (except serotype O28ac: $\mathrm{H}$ that did not produce the $76 \mathrm{kDa}$ protein). Several strains $\left(\mathrm{O} 29: \mathrm{H}^{-}, \mathrm{O} 144: \mathrm{H}^{-}, \mathrm{O} 152: \mathrm{H}^{-}\right.$, and $\left.\mathrm{O} 167: \mathrm{H}^{-}\right)$expressed IutA in the outer membrane, in the absence of aerobactin production. Additionally to well characterized proteins (FepA and IutA), we found two IROMP of unknown function in some serotypes: a $71 \mathrm{kDa}$ protein was detected in three profiles and a $67 \mathrm{kDa}$ protein was present in serotype $\mathrm{O} 152: \mathrm{H}^{-}$. Moreover, two bands (39 and $43 \mathrm{kDa}$ ) which were not iron-regulated bound specifically to human lactoferrin.
\end{abstract}

Key words: enteroinvasive $E$. coli, iron uptake

\section{INTRODUCTION}

Iron is very important for all organisms because it participates in many biochemical and metabolic processes, including steps of the electron transfer through the respiratory chain and DNA synthesis. Fe III oxides are quite stable but insoluble at neutral $\mathrm{pH}$, therefore free Fe III is limited to an equilibrium concentration of approximately $10^{-18} \mathrm{M}(12)$, a value far below the one needed for the optimal growth in microbes $\left(10^{-8}\right.$ to $\left.10^{-6} \mathrm{M}\right)$. In mammalian hosts, most iron is sequestered intracellularly in heme and ferritin, or extracellularly in carrier glycoproteins such as transferrin in serum and lactoferrin on mucosal surfaces $(2,17,28)$.

To survive in the host, many pathogenic bacteria evolved iron-transport systems to utilize host iron compounds. Under conditions of iron deprivation, most Gram-negative bacteria produce: (i) siderophores, iron chelators that are able to efficiently remove iron from transferrin or lactoferrin and (ii) outer membrane proteins (OMPs), that function as receptors for ferric siderophores and ferric proteins (12).

Iron-regulated outer membrane proteins (IROMPs) of enteric bacteria mediate siderophore uptake and have apparent molecular masses in the range of 74 to $84 \mathrm{kDa}$ (26). In E. coli receptors with $81 \mathrm{kDa}$ and $74 \mathrm{kDa}$ bind ferric enterobactin and ferric aerobactin, respectively. The iron uptake system for hemin in Shigella and EIEC strains involves an IROMP of $100 \mathrm{kDa}$, whereas in enterohemorragic $E$. coli strains (EHEC) the same process uses an outer membrane receptor of $69 \mathrm{kDa}(30,33)$.

E. coli comprises several clones which together have evolved the ability to cause a broad spectrum of human diseases (25).

EIEC are diarrhea-causing strains pathogenically related to Shigella sp. The role played by EIEC in endemic diarrheal disease has not been investigated extensively. However, some studies indicated that these bacteria can be isolated with relatively high frequency depending on the population investigated (32).

\footnotetext{
* Corresponding author. Mailing address: Departamento de Análises Clínicas e Toxicológicas, Faculdade de Ciências Farmacêuticas, USP, Av. Prof. Lineu Prestes, 580, CEP 05508-900, São Paulo, SP, Brasil. Fax: (+5511) 3813-2197. E-mail: mbmartin@usp.br
} 
The mechanisms of iron uptake by EIEC are largely unknown. In a work carried out in our laboratory previously, all EIEC strains studied were able to produce siderophores, enterobactin and/or aerobactin. Those strains were checked for their ability to use iron from different host sources, such as heme compounds and the glycoproteins transferrin and lactoferrin. All sources were used by EIEC strains (8). In the present article, the EIEC IROMPs were studied.

\section{MATERIALS AND METHODS}

Bacterial strains and growth conditions. Thirty EIEC strains of different serotypes isolated from patients with acute diarrhea were used. Cultures were grown at $37^{\circ} \mathrm{C}$ under shaking for 6 hours in $100 \mathrm{ml}$ of Luria-Bertani Broth (LB - Triptone $10 \mathrm{~g}$, yeast extract $5 \mathrm{~g}, \mathrm{NaCl} 10 \mathrm{~g}, \mathrm{NaOH} 1 \mathrm{~N} 2.5 \mathrm{ml}, \mathrm{H}_{2} \mathrm{O}$ d $1 \mathrm{~L}$ ), which was supplemented with thiamine $(20 \mu \mathrm{L} / \mathrm{ml})$ and tryptophan $(40 \mu \mathrm{l} / \mathrm{ml})$ (Difco Laboratories Detroit, Michigan USA) and $150 \mu \mathrm{M}$ of $\mathrm{FeCl}_{3}$ (Merck KG Darmstadt, Germany). For iron starvation, FeIII was removed by $200 \mu \mathrm{M}$ of $\alpha$ $\alpha$ 'dypirydil (Sigma CO St. Louis, MO USA).

Detection of siderophores. Enterobactin and aerobactin were detected by Arnow (3) and Csaky (7) assays, respectively, conducted by Dr. Shelley Payne (Dept. of Microbiology-Univ. of Texas, Austin-USA).

Isolation of iron-regulated outer membrane proteins (IROMPs). IROMPs were isolated by the method described by Achtman et al. (1) with minor modifications. Thirty EIEC strains (Table 1) were grown under shaking $(1400 \mathrm{rpm})$ at $37^{\circ} \mathrm{C}$ for 6 hours in two different conditions in $100 \mathrm{ml}$ medium aliquots: in the presence and absence of iron. The cells were recovered by centrifugation $\left(4,300 \times g\right.$ for $15 \mathrm{~min}$ at $\left.4^{\circ} \mathrm{C}\right)$, suspended in $5 \mathrm{ml}$ of $10 \mathrm{mM}$ TRIS (Amershan Life Science, Cleveland, OHIO USA) buffer $\mathrm{pH} 8$, supplemented with $1 \mathrm{mM}$ phenylmethylsulfenylfluoride (PMSF) (Sigma CO St. LOUIS, MO USA).

Cells were disrupted by sonication at $50 \%$ output, $2 \mathrm{x}$ $80 \mathrm{sec}$., and the cells debris removed by centrifugation. The supernatant was centrifuged at $49,500 \times \mathrm{g}$ for 60 minutes at $4^{\circ} \mathrm{C}$ and the pellet treated with $1.67 \% \mathrm{~N}$-lauroylsarcosine (Sigma CO St. Louis, MO USA) for $20 \mathrm{~min}$ at room temperature. The outer membrane was recovered by centrifugation at $23,000 \times \mathrm{g}$ for $90 \mathrm{~min}$ at $4^{\circ} \mathrm{C}$. The pellet was resuspended in $50 \mu \mathrm{l}$ of $10 \mathrm{mM}$ TRIS buffer $\mathrm{pH} 8.0$ with $1 \mathrm{mM}$ PMSF. The proteins were quantified by the Bradford method (5) and maintained at $-20^{\circ} \mathrm{C}$.

Analysis of IROMPs. OMP preparations were solubilized at $100^{\circ} \mathrm{C}$ for 5 minutes in $0.05 \mathrm{M}$ Tris- $\mathrm{HCl}$ buffer containing 2.5\% SDS (Pharmacia Biotech AB Uppsala, Sweden) $10 \%$ mercaptoethanol (Merck KG Darmstadt, Germany), and $0.003 \%$ bromophenol-blue (Pharmacia Biotech AB Uppsala, Sweden). The proteins were separated by sodium dodecyl sulfate-polyacrylamide gel electrophoresis (SDS-PAGE, 5\% stacking, 12\% separating gel) (16). The protein bands were visualized by silver stain (19) and analyzed by densitometry (Densitometer GS700, BioRad Laboratories Hercules, CA, USA). For detection of specific receptors, proteins were transferred to nitrocellulose paper using Pharmacia apparatus and treated as described by Towbin et al (34). Aerobactin receptor protein band (IutA) was detected by using rabbit antiserum raised against the $74 \mathrm{kDa}$ IROMP expressed by pColV-K30 (36). The antibody was raised in 6-months-old New Zeland white rabbit by subcutaneous injections of crushed polyacrylamide gel fragments containing the $74 \mathrm{kDa}$ band. Enterobactin receptor protein band (FepA) was detected by using mouse monoclonal anti-FepA provided by Dr. Phillip Klebba (Dept. of Chemistry and Biochemistry of Oklahoma, OK. USA). Secondary antibodies were peroxidase-conjugate goat anti-rabbit and anti-mouse antibodies. Diamino-benzidine (DAB) (Sigma CO St. Louis, MO USA) and $\mathrm{H}_{2} \mathrm{O}_{2}$ (Merck S.A RJ, Brazil) were used as peroxidase substrate.

Detection of human lactoferrin (HLf) receptor protein band. The OMPs were separated by SDS-PAGE and transferred to nitrocellulose membrane by the methods described above. The preparations were blocked with a gelatin solution 5\% (Difco Laboratories Detroit Michigan USA), Tween 20 (Labsynth SP-Brazil) $0.2 \%$ in $0.01 \mathrm{M}$ PBS pH 7.4 for 2 hours at $37^{\circ} \mathrm{C}$. After blocking, the membranes were treated with a HLf (Sigma CO St. Louis, MO USA) solution $(50 \mu \mathrm{g} / \mathrm{ml})$, for 1 hour at $37^{\circ} \mathrm{C}$ under shaking, the protein was diluted in a solution of $1 \%$ gelatin, $0.05 \%$ Tween-20 in $0.01 \mathrm{M}$ PBS pH 7.4. HLf receptor protein band was detected by using 1:4,000 rabbit antiserum against HLf (Sigma CO St. Louis, MO USA) diluted in the same solution above for 30 minutes at $37^{\circ} \mathrm{C}$, followed by peroxidase-conjugate goat anti-rabbit antibody and it was visualized with the $\mathrm{DAB} / \mathrm{H}_{2} \mathrm{O}_{2}$ system.

DNA probes. The 1.8 -kbp aerobactin probe and $2.32-\mathrm{kbp}$ iut A probe were reported earlier (10). The probes were obtained by digesting pGMVIwith Pst 1 and PvuII (1.8-kbp and a 2.32kbp restrictions fragments, respectively) (Gibco BRL Grand Island, NY USA). The probes were labelled with biotin by Bioprime $^{\circledast}$ DNA Labeling System (Gibco BRL Grand Island, NY USA). The hybridization was detected by Blugene ${ }^{\circledR}$ Nonradioactive Nucleic Acid Detection System Kit (Gibco BRL Grand Island, NY USA). Hybridization with either probe was repeated at least twice.

Colony blot hybridization. DNA hybridization of the EIEC strains described above was done using the aerobactin and the iutA probes under high-stringency conditions as previously described $(21,24)$. For each probe, a colony was considered positive when it gave a clear-cut dark spot or negative if it gave a light "shadow" reaction or no reaction at all. 


\section{RESULTS}

Presence of the siderophore system in enteroinvasive E. coli. All 30 EIEC strains tested produced enterobactin and twelve (40\%) produced aerobactin. The EIEC serotypes showed differences regarding the kind of siderophores synthesized (Table 1). Strains belonging to the serotypes $\mathrm{O} 28 \mathrm{ac}: \mathrm{H}^{-}, \mathrm{O} 29: \mathrm{H}^{-}$, $\mathrm{O} 144: \mathrm{H}^{-}, \mathrm{O} 152: \mathrm{H}^{-}$, and $\mathrm{O} 167: \mathrm{H}^{-}$produced enterobactin, while serotypes $\mathrm{O} 112: \mathrm{H}^{-}, \mathrm{O} 124: \mathrm{H}^{-}, \mathrm{O} 136: \mathrm{H}^{-}, \mathrm{O} 143: \mathrm{H}^{-}$, and O164: $\mathrm{H}^{-}$showed production of both kinds of siderophores.

Electrophoretic profile of IROMPs of different serotypes of EIEC. The 30 strains studied showed IROMPs varying from 67-82 $\mathrm{kDa}$. The proteins were either induced or stimulated by the iron starvation (Table 1 and Fig. 1). Differences were observed in the electrophoretic profile among the serotypes, which produced 5 electrophoretic patterns. Densitometric analysis (data not shown) of the IROMPs showed quantitative differences in the profile of proteins from each group. By densitometry it was observed that some proteins are present at low levels in iron-replete medium, undergoing substantial increase of expression by iron-starvation. This pattern of expression was referred as "iron-stimulated". Alternatively, some proteins are not found in iron-replete medium, their pattern of expression was defined as "iron-induced". For instance, samples of Profile II $\left(\mathrm{O} 29: \mathrm{H}^{-}, \mathrm{O} 112: \mathrm{H}^{-}, \mathrm{O} 164: \mathrm{H}^{-}\right.$and $\left.\mathrm{O} 167: \mathrm{H}^{-}\right)$express FepA and IutA, but in two serotypes $\left(\mathrm{O} 29: \mathrm{H}^{-}\right.$ and $\left.\mathrm{O} 112: \mathrm{H}^{-}\right)$FepA expression was iron-stimulated, and IutA expression was iron-induced. In serotype O164: $\mathrm{H}^{-}$both receptors were iron-stimulated whereas in serotype $0167: \mathrm{H}^{-}$ both receptors were iron-induced (see Table 1).

Detection of receptors for aerobactin (IutA) and enterobactin (FepA). In order to detect the receptors for $\mathrm{Fe}$ -

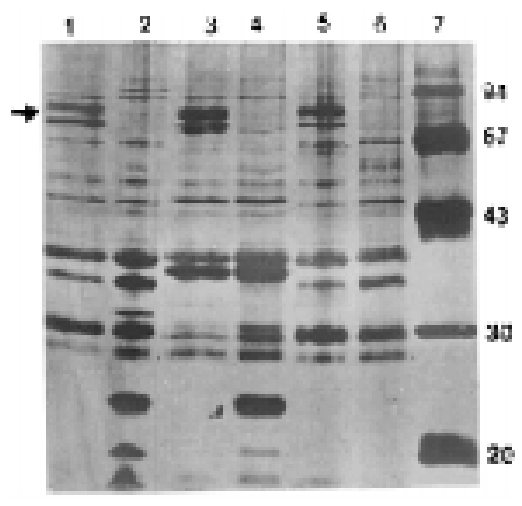

Figure 1. Outer membrane proteins regulated by iron of EIEC strains. Each lane contains $10 \mu \mathrm{g}$ of proteins.

Lane 1 and 2 - O136:NM; lane 3 and 4 - O143:NM; lane 5 and 6 O144:NM; lane 7 MW. Lane 1, 3, and 5 strains were grown in iron starvation medium. Lane 2, 4, and 6 strains were grown in medium supplemented with $\mathrm{FeCl}_{3}(150 \mu \mathrm{M})$. The protein profile of each strains was analysed by SDS-PAGE and staining with silver stain. The arrow indicates the region induced or stimulated by iron.

Enterobactin and Fe-Aerobactin in EIEC IROMPs, immunobloting assays were carried out with anti-FepA monoclonal serum and anti-IutA policlonal serum, respectively. The monoclonal serum anti-FepA recognized a band of $82 \mathrm{kDa}$ in all the strains, as expected (Fig. 2A). The serum anti-IutA revealed the protein of $76 \mathrm{kDa}$ in the EIEC serotypes that produced this protein (Fig. 2B).

Detection of genes for aerobactin and its receptor protein (IutA). All serotypes studied except $\mathrm{O} 28 \mathrm{ac}: \mathrm{H}^{-}$ expressed the receptor for aerobactin, IutA, but strains of serotypes $\mathrm{O} 29: \mathrm{H}^{-}, \mathrm{O} 144: \mathrm{H}^{-}, \mathrm{O} 152: \mathrm{H}^{-}$and $\mathrm{O} 167: \mathrm{H}^{-}$were

Table 1- Probable molecular masses of the OMP and their electrophoretic migration profile of the different serotypes of enteroinvasive E.coli grown in iron starvation

\begin{tabular}{cccccccc}
\hline Strains & Serotypes & Aerobactin & Enterobactin & $\begin{array}{c}\text { Protein } \\
\text { Bands } \\
(\mathrm{kDa})\end{array}$ & $\begin{array}{c}\text { Electrophoretic } \\
\text { Profile }\end{array}$ & $\begin{array}{c}\text { Induced } \\
\text { Protein } \\
\text { Bands }\end{array}$ & $\begin{array}{c}\text { Stimulated } \\
\text { Protein } \\
\text { Bands }\end{array}$ \\
\hline $1,2,3$ & $\mathrm{O} 28 \mathrm{ac}: \mathrm{H}^{-}$ & 0 & 3 & 82,71 & $\mathrm{I}$ & - & 82,71 \\
$10,11,12$ & $\mathrm{O} 29: \mathrm{H}^{-}$ & 0 & 3 & 82,76 & II & 76 & 82 \\
$15,16,17$ & $\mathrm{O} 112: \mathrm{H}^{-}$ & 1 & 3 & 82,76 & II & 76 & 82 \\
$18,19,20$ & $\mathrm{O} 124: \mathrm{H}^{-}$ & 3 & 3 & $82,78,76,71$ & III & 71 & $82,78,76$ \\
$21,22,23$ & $\mathrm{O} 136: \mathrm{H}^{-}$ & 2 & 3 & $82,78,76$ & IV & - & $82,78,76$ \\
$24,25,26$ & $\mathrm{O} 143: \mathrm{H}^{-}$ & 3 & 3 & $82,78,76,71$ & III & 82 & $78,76,71$ \\
$27,28,29$ & $\mathrm{O} 144: \mathrm{H}^{-}$ & 0 & 3 & $82,78,76$ & IV & 82,76 & 78 \\
$30,31,32$ & $\mathrm{O} 152: \mathrm{H}^{-}$ & 0 & 3 & $82,76,71,67$ & V & $82,76,67$ & 71 \\
$33,34,35$ & $\mathrm{O} 164: \mathrm{H}^{-}$ & 3 & 3 & 82,76 & II & - & 82,76 \\
$38,39,40$ & $\mathrm{O} 167: \mathrm{H}^{-}$ & 0 & 3 & 82,76 & II & 82,76 & - \\
\hline
\end{tabular}


consistently negative in the screening of aerobactin siderophore production. The probes $1.8 \mathrm{~kb}-P s t 1$ and $2.32 \mathrm{~kb}$ $P v u I I$ were used for detecting the aerobactin and receptor genes in the serotypes that have not produced aerobactin but otherwise produced the receptor IutA $(76 \mathrm{kDa})$. The probe for aerobactin genes produced positive reaction to serotypes $\mathrm{O}: 29: \mathrm{H}^{-}, \mathrm{O} 112: \mathrm{H}^{-}, \mathrm{O} 124: \mathrm{H}^{-}, \mathrm{O} 136: \mathrm{H}^{-}, \mathrm{O} 143: \mathrm{H}^{-}, \mathrm{O} 144: \mathrm{H}^{-}$, $\mathrm{O} 152: \mathrm{H}^{-}, \mathrm{O} 164: \mathrm{H}^{-}$and $\mathrm{O} 167: \mathrm{H}^{-}$: in these strains the genes for aerobactin-mediated iron transport were present, but aerobactin was not always produced (see Table 1).

Detection of human lactoferrin (HLf) receptor protein band. The use of polyclonal rabbit anti-serum and the nonspecific binding of HLf to a number of proteins $(23,29)$ led us to pre-absorb the serum with E. coli K12 cells. This procedure substantially reduced non specific reaction, allowing us to detect a specific band of $39 \mathrm{kDa}$ in all strains analyzed. An additional $43 \mathrm{kDa}$ band was present in 17 of the strains tested (Fig. 2C). The strains expressed these proteins independent of iron availability.
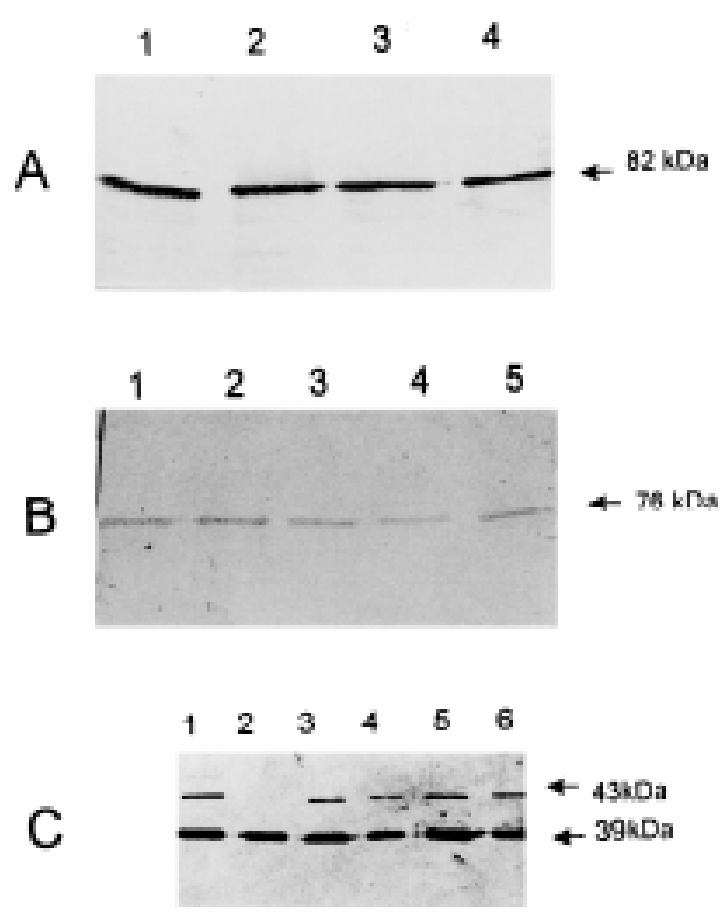

Figure 2. Western-blot analysis of outer membrane proteins of EIEC strains. (A) - immunoblot using mouse monoclonal anti-FepA. 1 O28ac:NM; 2 - O124:NM; 3 - O143:NM; 4 - O144:NM. (B) immunoblot using rabbit polyclonal serum anti-IutA. 1 - O124:NM; 2 - O29:NM; 3 - O144:NM; 4 - O152:NM; 5 - O167:NM. (C) immunoblot using rabbit polyclonal serum anti-human lactoferrin. 1 - O28ac:NM; 2 - O28ac:NM; 3 - O136:NM; 4 - O144:NM; 5 O152:NM; 6 - O152:NM.

\section{DISCUSSION}

The low availability of free iron in mammalian tissues is the cause for the development of complex systems of iron acquisition in virulent bacteria. In fact, many reports in the scientific literature demonstrate the influence of iron on bacterial virulence (12).

In the present article, some aspects of iron uptake systems exhibited by a collection of EIEC strains belonging to 10 different serotypes were analyzed. High affinity iron uptake systems were expressed by EIEC strains under iron-limiting growth conditions. All 30 strains studied for siderophore produced the phenolic siderophore enterobactin, and 12 produced in addition the hydroxamic siderophore aerobactin.

The analysis of the outer membrane proteins expressed under iron starvation allowed us to divide the EIEC strains in five electrophoretic profiles, as shown in Table 1. Contrary to what it found for the ability of EIEC to use iron compounds (8), the pattern of expression of IROMPs is serotype-specific. We investigated the regulation of expression of the major IROMP by growing the cells in iron-replete medium and ironlimited medium, separating their outer membranes and subjecting them to SDS-PAGE. Earlier report has been shown variations in IROMPs expression due the chelators used to restrict the availability of iron (6). It has been shown that E.coli O164 did not produce $81 \mathrm{kDa}$ IROMP, when it is growing in TSB medium containing $\alpha-\alpha$ ' dipyridyl, but expressed $83 \mathrm{kDa}$, $81 \mathrm{kDa}, 78 \mathrm{kDa}, 76 \mathrm{kDa}$ and $74 \mathrm{kDa}$ IROMPs under EDDA or desferral as iron chelators (6). However, our observations showed that strains of E.coli O164 express $82 \mathrm{kDa}$ and $76 \mathrm{kDa}$ IROMPs under LB medium with $\alpha$ - $\alpha$ 'dipyridyl chelator. This results lead us to suggest that expression of IROMPs is also medium dependent.

Several reports have shown that iron starvation of E.coli leads to the expression of IROMPs of $83,81,78$ and $74 \mathrm{kDa}$ $(6,15,26)$. With the exception of the $83 \mathrm{kDa}$ protein, all others have been characterized to some extent: the $81 \mathrm{kDa}$ protein, known as FepA, is the receptor for ferric enterobactin and for the protein toxins colicins $\mathrm{B}$ and $\mathrm{D}(14,22,35)$; the $78 \mathrm{kDa}$ protein is the receptor for ferrichrome, TonA (38); and the $74 \mathrm{kDa}$ protein is the receptor for aerobactin, lutA $(4,37)$.

In our samples, all serotypes expressed proteins of 82 and $76 \mathrm{kDa}$ (except serotype O28ac: $\mathrm{H}^{-}$that did not produce the $76 \mathrm{kDa}$ receptor). Immunoblots showed that the $82 \mathrm{kDa}$ protein is the ferric enterobactin receptor FepA (Fig. 2A), and the $76 \mathrm{kDa}$ protein is the receptor IutA (Fig. 2B). The $78 \mathrm{kDa}$ protein, found in serotypes $\mathrm{O} 124: \mathrm{H}^{-} ; \mathrm{O} 136: \mathrm{H}^{-}, \mathrm{O} 143: \mathrm{H}^{-}$, and $\mathrm{O} 144: \mathrm{H}^{-}$is probably TonA.

Earlier reports in the literature state that E.coli strains that do not produce aerobactin also lack its outer membrane receptor, IutA $(18,11)$. However, several of the strains analyzed in the present study $\left(\mathrm{O} 29: \mathrm{H}^{-}, \mathrm{O} 144: \mathrm{H}^{-}, \mathrm{O} 152: \mathrm{H}^{-}\right.$, and $\left.\mathrm{O} 167: \mathrm{H}^{-}\right)$ 
expressed IutA in the outer membrane, in the absence of aerobactin production. Indeed, Payne et al (27) isolated samples of $S$. flexneri that were unable to produce aerobacin, but utilized exogenously supplied aerobactin, suggesting that in some samples, expression of the outer membrane receptor happens independently of siderophores production. Our results corroborate their findings.

Additionally to well characterized IROMPs (FepA, TonA, IutA), we found two proteins of unknown function in some serotypes: a $71 \mathrm{kDa}$ protein was detected in all serotypes of profiles I, III, and V; a $67 \mathrm{kDa}$ protein was present in serotype O152: $\mathrm{H}^{-}$, profile $\mathrm{V}$. At the moment, we do not know the function of these IROMPs and to our knowledge these proteins have not been previously described in the literature. The fact that those receptors are expressed exclusively under iron starvation suggests their involvement in some kind of iron uptake. However, it may also be a virulence factor subjected to ironregulation. Human lactoferrin outer membrane receptor was researched by different workers. Several of them have shown that porins of enterobacteria OmpC (39 kDa) and $\mathrm{OmpF}$ $(37 \mathrm{kDa})$ bind lactoferrin $(9,31)$. HLf is probably a relevant source of iron for EIEC, due to its presence in gastrointestinal mucosal surfaces. In a study performed in our laboratory, several EIEC strains were able to use HLf (8). We investigated the binding of HLf to outer membrane receptors and two bands ( 39 and $43 \mathrm{kDa}$ ) showed binding specificity to HLf, and neither was iron-regulated. The $39 \mathrm{kDa}$ receptor is probably OmpC, that has been previously shown to bind $\operatorname{HLf}(9,31)$. EIEC and $S$. flexneri strains produce a OMP of $43 \mathrm{kDa}$ that functions in the invasion mechanism (IpaC) (13). Tigyi et al (31) have shown three OMP in S. flexneri that are able to bind HLf (39, 22 , and $16 \mathrm{kDa}$ ). No $43 \mathrm{kDa}$ receptor was vizualized in that study. These data suggest that the $43 \mathrm{kDa}$ protein that binds HLf observed in EIEC strains is different from $43 \mathrm{kDa}$ protein involved in the invasion mechanisms. The fact that $43 \mathrm{kDa}$ protein was not iron-regulated suggests that the binding of HLf to it may not represents the first step of productive iron uptake, in turn this protein can be involved in other methabolic pathways.

We are presently using biochemical and genetic approaches to answer questions concerning the $71 \mathrm{kDa}, 67 \mathrm{kDa}$ and $43 \mathrm{kDa}$ proteins produced by EIEC.

\section{ACKNOWLEDGEMENTS}

This study was supported by grant 94/30114-0 from Fundação de Amparo à Pesquisa do Estado de São Paulo (FAPESP) and CAPES and CNPq Graduate grant fellowship. We thank Dr. Shelley Payne for siderophores detection. We also thank Dr. Phillip Klebba for helpful discussion and advice. Thanks Dr. Marilda C. Vidotto for the probes used in this study.

\section{RESUMO}

\section{Mecanismos de captação de ferro de Escherichia coli enteroinvasora}

Cepas de Escherichia coli enteroinvasora de diferentes sorotipos isoladas de pacientes com diarréia aguda foram examinadas quanto a capacidade de produzir sideróforos e proteínas de membrana externa reguladas pelo ferro (IROMP). $\mathrm{O}$ crescimento bacteriano em meio com deficiência em Fe foi obtido em caldo Lúria acrescido de $200 \mathrm{mM}$ de $\alpha$ - $\alpha$ 'dipiridil. Todas as cepas produziram enterobactina e $40 \%$ produziram aerobactina. As cepas produziram IROMPs com MM variando de 82-67 kDa. As proteínas foram induzidas ou estimuladas pela deficiência de ferro. Diferenças foram observadas no perfil eletroforético entre os sorotipos, originando 5 perfis eletroforéticos. Todos os sorotipos, com exceção do sorotipo O28ac: $\mathrm{H}^{-}$(onde a proteína de $76 \mathrm{kDa}$ não foi produzida), expressaram proteínas de $82 \mathrm{kDa}$ (FepA) e $76 \mathrm{kDa}$ (IutA).

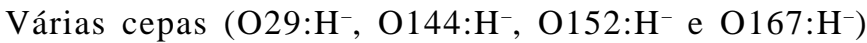
expressaram IutA na membrana externa, na ausência da produção de aerobactina. Além das proteínas (FepA e IutA), foram encontradas em alguns sorotipos duas IROMPs de função desconhecida: uma proteína de $71 \mathrm{kDa}$ foi detectada em 3 perfis e uma de $67 \mathrm{kDa}$ presente no sorotipo $\mathrm{O} 152: \mathrm{H}^{-}$. Além disso, 2 bandas (39 e $43 \mathrm{kDa}$ ), as quais não foram reguladas pelo ferro, mostraram afinidade à lactoferrina humana.

Palavras-chave: Escherichia coli enteroinvasora, captação de ferro.

\section{REFERENCES}

1. Achtman, M.; Mercer, A.; Kusecek, B.; Heuzenroeder, M.; Pohl, A.; Aronson, W.; Sutton, A.; Silver, P.R. Six widespread bacterial clones among Escherichia coli $\mathrm{K} 1$ isolates. Infect. Immun., 39: 315-335, 1983.

2. Aisen, P.; Leibman, A. Lactoferrin and transferrin, a comparative study. Biochem Biophys. Acta., 257: 314-323, 1972.

3. Arnow, L.E. Colorimetric determination of the components of 3,4dihydroxyphenylalanine-tyrosine mixtures. J. Biol. Chem., 228: 531-537, 1937.

4. Bindereif, A.; Braun, V.; Hantke, K. The cloacin receptor of ColV bearing E.coli is part of the FeIII- aerobactin transport system. J. Bacteriol ., 150: 1472-1475, 1982.

5. Bradford, M.M. A rapid and sensitive method for the quantitation of microgram quantities of protein utilizing the principle of protein-dyebinding. Anal. Biochem., 72: 248-254, 1976.

6. Chart, H.; Buck, M.; Stevenson, P.; Griffiths, E. Iron regulated outer membrane proteins of Escherichia coli: variations in expression due to the chelator used to restrict the avalability of iron. J. Gen. Microbiol., 132: 1373-1378, 1986.

7. Csaky, T.Z. On the estimation of bound hydroxylamine in biological materials. Acta. Chem. Scand., 2: 450-454, 1948.

8. Dall'Agnol, M.; Martinez, B.M. Iron uptake from different compounds by enteroinvasive Escherichia coli. Rev. Microbiol. (in press)1999.

9. Erdei, J.; Forsgren, A.; Naidu, S.S. Lactoferrin bind to porins OmpF and OmpC in Escherichia coli. Infect. Immun., 62: 1236-1240, 1994.

10. Góes, C.R.; Gaziri, L.C.J.; Vidotto, M.C. Cloned genes of the aerobactin system of virulent avian Escherichia coli do not confer virulence to recombinant strains. Brazilian J. Med. Biol. Res., 26: 261-275, 1993. 
11. Griffithis, E.; Stevenson, P.; Hale, T.L.; Formal, S.B. Synthesis of aerobactin and a $76000 \mathrm{Da}$ iron-regulated outer membrane protein by Escherichia coli K-12-Shigella flexneri hybrids and by enteroinvasive strains of Escherichia coli. Infect. Immun., 49: 67-71, 1985.

12. Guerinot, L.M. Microbial iron transport. Annu. Rev. Microbiol., 48: 743772,1994

13. Hale, T.L.; Sansonetti, P.J.; Schad, P.A; Austin, S.; Formal, S.B. Characterization of virulence plasmids and plasmid-associated outer membrane proteins in Shigella flexneri, Shigella sonnei and Escherichia coli. Infect. Immun., 40: 340-350, 1983.

14. Hollifield, W.C.; Neilands, J.B. Ferric enterobactin transport system in Escherichia coli K12. Extraction, assay, and specificity of the outer membrane receptor. Biochem., 17:1922-1928, 1978.

15. Klebba, P.E.; McIntosh, M.A; Neilands, J.B. Kinetics of biosyntesis of ironregulated membrane proteins in E.coli. J. Bacteriol., 149: 880-888, 1982.

16. Laemmli, V.K. Cleavage of structural proteins during the assembly of the head of bacteriophage T4. Nature. 227: 680-685, 1970

17. Litwin, M.C.; Calderwood, B.S. Role of iron in regulation of virulence genes. Clin. Microbiol. Rev., 6: 137-149, 1993.

18. Marolda, C.L.; Valvano, M.A; Lawlor, K. M.; Payne, S.M.; Crosa, J.H. Flanking and internal regions of chromosomal genes mediating aerobactin iron uptake systems in enteroinvasive Escherichia coli and Shigella flexneri. J. Gen. Microbiol., 133: 2269-2278, 1987.

19. Marryel, C.R.; Pratt, M.E. A silver stain for the rapid quantitative detection of proteins or nucleic acids on membranes or thin-layer plates. Anal. Biochem., 156: 96-110, 1986

20. Martinez, B.M.; Whittan, T.S.; McGrow, E.A.; Rodrigues, J.; Trabulsi, L.R. Clonal relationship among enteroinvasive Escherichia coli. FEMS. Microbiol. Letters., 172:145-151, 1999.

21. Mass, R. An improved colony hybridization method with significanty sensitivity for detection of single genes. Plasmid., 10: 296-298, 1983.

22. McIntosh, M.; Earhart, C.F. Effect of iron on the relative abundance of two large polypeptides of the Escherichia coli outer memmbrane. Biochem. Biophys. Res. Commun., 70: 315-322, 1976.

23. Miyazawa, K.; Mantel, C.; Lu, L.; Morrison, D.C.; Boxmeyer, H.E. Lactoferrin-lipopolysaccharide interactions: effect on lactoferrin binding to monocyte/macrophage-differentiated HL-60 cells. J. Immunol ., 146: 723729, 1991.

24. Moseley, S.L.; Huq, I.; Alim, A., So, M.; Samad-Pour-Motalebi, M.; Falkow, S. Detection of enterotoxigenic Escherichia coli by DNA colony hybridization. J. Infect. Dis., 142: 892-898, 1980.
25. Nataro, J.P.; Kaper, J. B. Diarrheagenic Escherichia coli. Clin. Microbiol. Rev., 11: 142-201, 1998.

26. Neilands, J.B. Microbiol envelope proteins related to iron. Annu. Rev. Microbiol., 36: 285-309, 1982.

27. Payne, S.M.; Niesel, D.W.; Peixoto, S.S.; Lawlor, K.M. Expression of hidroxamate and phenolate siderophores by Shigella flexneri. J. Bacteriol., 155: 949-955, 1983.

28. Payne, S.M. Iron acquisition in microbial pathogenesis. Trends. Microbiol., 1: 66-69, 1993

29. Schryvers, A.B.; Morris, L.J. Identification and characterization of the human lactoferrin-binding protein from Neisseria meningitidis. Infect. Immun ., 56 1144-1149, 1988.

30. Stugard, C.E.; Daskaleros, P.A; Payne, S.M. A 101 kDa M-binding protein associated with congo red binding and virulence of Shigella flexneri and enteroinvasive E.coli strains. Infect. Immun., 57: 3534-3539, 1989.

31. Tigyi, Z.; Kishore, A.R.; Maeland, J.A; Forsgren, A.; Naidu,, A.S. Lactoferrinbinding proteins in Shigella flexneri. Infect. Immun., 60: 2619-2629, 1990.

32. Toledo, M.R.F.; Trabulsi, L.R. Frequency of enteroinvasive Escherichia coli in children with diarrhea and healthy controls, in São Paulo, SP, Brazil. Rev. Microbiol., 21: 1-4, 1990.

33. Torres, A.G.; Payne, S.M. Haem iron-transport system in enterohaemorragic Escherichia coli O157:H7. Mol. Microbiol., 23: 825-833, 1997.

34. Towbin, H.; Staehelin, T.; Gordon, J. Electrophorectic transfer of proteins from polyacrylamide gels to nitrocellulose sheets: procedure and some applications. Proc. Natl. Acad. Sci. USA ., 76: 4350-4354, 1979.

35. Uemura, J.; Mizushima, S. Isolation of outer membrane proteins of Escherichia coli and their characterization on polyacrylamide gel. Biochem. Biophys. Acta ., 413: 163-176, 1975.

36. Valvano, M.A; Silver, R.P.; CROSA, J.H. Aerobactin iron transport genes commonly encoded by certain ColV plasmids occur in the chromosome of a human invasive strain of Escherichia coli K1. Infect. Immun ., 46: 159-167, 1984.

37. Vantiel-Menkveld, G.J.; Mentjox-Vervuurt, M.J.; Oudega, B.; Graaf, K.F. Siderophore production by Enterobacter cloacae and common receptor protein for the uptake of aerobactin and cloacin DF13. J. Bacteriol ., 150: 490-497, 1981

38. Wayne, R.; Neilands, J.B. Evidence for common binding sites for ferrichrome compounds and bacteriophage $\mathrm{f} 80$ in the cell envelope of Escherichia coli. J. Bacteriol., 121: 497-503, 1975. 